\title{
Halk Anlatılarının Epik Kuralları Bağlamında Konstantin İvanov’un Narspi Manzumesi ${ }^{1}$
}

\section{Mehmet TUNCER²}

\begin{abstract}
$\ddot{\mathbf{O} z}$
Sözlü gelenek üzerinden varlığını yüzyıllarca devam ettiren ve 19.yy. başlarında yazılı hale gelmeye başlayan Çuvaş edebiyatında gerek muhtevası gerekse yazılışından sonraki çoğu ilmî çalışmaya kaynaklık etmesi bakımından önemli bir noktada bulunan Konstantin İvanov'un Narspi manzumesi, edebî metinlerin inşâsında sözlü anlatıların, folklorik unsurların rolünü ve halk edebiyat verimlerinin farklı edebî metinlere şekil, konu, yapı ve üslup bakımından kaynaklık ettiğini göstermesi açısından dikkate değerdir. Bu bağlamda çalışmamızda, edebi üretimde evrensel geçerliliği olan konunun birliği, yoğunlaşma, yapı ve mantık gibi genel kurallar olarak nitelendirebileceğimiz; Danimarkalı halk bilimci Axel Olrik’in geliştirdiği, bir araya getirilmiş yaygın benzerlik kategorilerinden elde edilmiş kurallar olan "Halk Anlatılarının Epik Kuralları” bağlamında Narspi manzumesi incelenerek; bu kuralların geleneksel halk anlatıları dışında, farklı kurgusal metinlere uygulanabilirliği gösterilmeye çalışılmıştır.
\end{abstract}

Anahtar kelimeler: Narspi, Epik Kurallar, Halk Kültürü, Halk Anlatıları.

\section{Konstantin İvanov's Narspi Poem Within The Context Of Epic Rules Of Public Narratives}

\begin{abstract}
Konstantin İvanov's Narspi poem has an important place in Chuvash literature which existed for centuries through oral tradition and began to be written in the 19th century. İvanov's Narspi poem acted as a source for the subsequent scholarly works due to its content and structure. It is important as it shows the role of the oral narratives and the folkloric elements in constructing the literary texts and it also shows that the folk narratives act as a source for different literary texts in terms of form, topic and style. The aim of this study in this regard is to examine Narspi poem within the scope of "epic rule of public narratives" which can be defined as universally valid general rules that include topic coherence, concentration, structure and logic and which has been developed by Danish folklorist Axel Olrik. Also the applicability of those rules to different fictive texts other than folk narratives has been discussed.
\end{abstract}

Keywords: Narspi, Epic Rules, Folk Culture, Folk Narratives.

\section{Giriş}

İnsanlığın, tarihin takip edilebilen en eski zamanlarından bu yana anlattığı ve dinlediği türler olmuştur. Çünkü anlatmak ve dinlemek insanın e tabiî ihtiyaçlarındandır. Dinleyerek öğrenme, zevk alma ve

\footnotetext{
1 Bu makale, 27.05.2015 tarihinde Rusya Federasyonu'na bağlı Çuvaş Özerk Cumhuriyeti'nin başkenti Çeboksarı'da, Çuvaş Özerk Cumhuriyeti Eğitim ve Gençlik Bakanlığı Çuvaş Devlet İnsani Bilimler Enstitüsü tarafindan düzenlenen "Konstantin İvanov ve Çuvaş Dünyası (Millî Kültür Bağlamında)" başlıklı sempozyumda sunduğumuz tebliğin yeniden gözden geçirilerek genişletilmiş halidir [Makale kayıt tarihi: 3.10.2017-kabul tarihi: 18.10.2017]; DOI: 10.2900o/rumelide.347557

$2 \quad$ Arş. Gör., Kırklareli Üniversitesi, Fen-Edebiyat Fakültesi, Türk Dili ve Edebiyatı Bölümü, folkloristuncer@yandex.com
} 
rahatlama biçimi, okumanın daha çok kişi tarafından bilinen bir durum halini alması ve yazılı kültürün yaygınlaşması üzerine okunan ve dinlenen türlerden zamanla yazılı türlere doğru geçişi getirmiştir (Argunşah, 2010, s.125).

Bununla birlikte "anlatma ve dinleme ihtiyacı ve bu ihtiyacın daha çok, en kolay yol olan sözle giderilmesi, sözlü anlatıların daima var olması noktasında onlara bir süreklilik kazandırmaktadır. Fakat bu süreklilik, onların her zaman aynı yapı ve muhtevaya sahip olduğu / olacağı anlamına da gelmemektedir" (Boyraz, 2008, s.108). Zira cemiyetlerin sosyal, siyasi ve ekonomik hayatlarındaki değişim ve dönüşümlerle anlatıları üreten ve tüketen insan zihni, anlatıların yaşatıldığı sosyal ortamlar, anlatıcılar tarafından oluşturulan gelenek de aynı kalmamıştır. Kimi zaman geçmişten tevârüs eden bazı kültürel unsurlar giderek revaçtan düşmüş hatta kaybolmaya yüz tutmuştur. Doğal olarak anlatmalara da yansıyan bu durum sözlü anlatım türleri için de geçerlidir ve bu değişim ve dönüşümler yeni anlatım türlerinin ortaya çıkmasına da zemin hazırlamıştır diyebiliriz. Ancak bu, eski anlatılara ait hususların büsbütün ortadan kalktığı manasına da gelmemektedir. Zira eski anlatım türlerindeki bazı unsurlar, özellikle de kimi motifler ya hepten korunarak ya da bazı değişim ve dönüşümler geçirerek yeni anlatım türlerinde, bazen bu yeni anlatım türlerinin temelini oluşturacak şekilde varllğını sürdürmektedir (Boyraz, 2008, s.108).

Bu bağlamda incelememize konu olan Çuvaş şair Konstantin İvanov’un Narspi Manzumesi, yazılı kültür ortamı ürünü olarak 1900'lü yılların başında kaleme alınmış olsa da varlığını sözlü gelenek üzerinden yüzyıllarca devam ettiren ve 19.yy. başlarında yazılı hale gelmeye başlayan Çuvaş edebiyatında gerek yazılışından sonraki çoğu ilmî çalışmaya kaynaklık etmesi gerekse yazılı-edebî metinlerin inşâsında sözlü anlatıların, folklorik unsurların rolünü ve halk edebiyatı verimlerinin kurgusal-modern metinlere şekil, konu, yapı ve üslup bakımından kaynaklık ettiğini göstermesi bakımından dikkate değerdir (Boyraz, 2008, s.108).

Konusu itibariyle benzerlerini varisi olduğumuz zengin Türk kültür dünyasının içerisinde kolaylıkla bulmak mümkün olsa da İvanov'un eserini önemli kılan, muhtevasında barındırdığı geleneksel Çuvaş kültürel unsurlarıyla, Ziya Gökalp’ten mülhem olarak söyleyecek olursak "Çuvaş Türklerinin ahenkli bir mecmuası" niteliğinde, milli bir hafıza/ bellek değerinde olmasıdır.

\section{Edebiyatın Kültürel Kimliği İnşadaki Rolü ve Narspi Manzumesi}

Jusdanis, bir milletin millet olabilmesi için iki şeye ihtiyacı olduğunu söyler: "Sınırlarını genişletmek ve kendi edebiyatını yaratmak" (Jusdanis, 1998, s.76). Bu ifade, kültürel kimliklerin yeniden inşasında, edebiyatın bu inşa sürecine katkısı anlamına da gelmektedir ki mili kültür, toplumsal belleğin mülküyse ve insanların duyarlılığına etki ederek, toplumsal bir mutabakat oluşturmada bir araç olarak kullanılacaksa, bu etkilemenin edebiyatın katkısıyla olacağı açıktır (Conoğlu, 2014, s.152).

Bilindiği üzere sanatın her formu, yeni bir dünya tasavvuru için önemli bir rol üstlenir. Sanatkârın duygu, düşünce ve hayalini, kısacası meramını ifade ettiği form/biçim ne olursa olsun hem onu oluşturan hem de istifadesine sunduğu insanlara bakan yönüyle eğitme, rahatlama, eğlendirme, kültür aktarımı vb. çeşitli işlevlerinin olduğu malumdur.

Bir sanat formu olarak edebiyat ise "ister sanat amaçlı ister fayda amaçlı ürünler versin, toplum hafızasının aynalığı vazifesini yaptığı için, geleneğin dönüştürülme/değiştirilme safhalarına da tanıklık 
yapar ve yazılan eserlere yerleştirilmiş unsurlar aracıllı̆ııla bunun okuyucuları arasında yayılmasını, kabul görmesini ve gelecek nesillere aktarılmasını kolaylaştırı»” (Sanlı, 2009, s.163).

Bu nokta-i nazarla Narspi manzumesine baktığımızda İvanov'un eserinde sadece geleneksel Türk toplumuna hiç de yabancı olmayan; babasının, yoksul ve yiğit Setner'den ayırıp, zengin ve yaşlı Tihtaman’la zorla evlendirdiği güzel Narspi'nin öyküsünü değil Çuvaşların eski köy yaşamlarını, örflerini, adetlerini, inançlarını, geleneklerini, değer yargılarını da görürüz. Çuvaşlar arasında sözlü kültür ortamında yaşamış ve bir kısmının hâlâ canlılığını sürdürdüğü türküler, bilmeceler, atasözleri bir takım gelenekler manzumenin zengin bir görünüm arz etmesini sağlamaktadır ki sözü edilen bu unsurlar, bireylere bir araya gelme ve millet olma özelliği kazandıran ortak değerlerdir ve bu unsurları kültür kavramı çerçevesinde değerlendirmek gerekir. Kültürel unsurların ziyadesiyle yer aldığı yazılı bir metin olarak Narspi manzumesi de, dolaylı olarak milli hafizanın tecessüm ettiği bir belge haline gelmektedir.

$\mathrm{Bu}$ noktada çalışmamızda öncelikle Konstantin İvanov ve Narspi Manzumesi hakkında Türkiye sahasında yapılan çalışmalar ışığında3 genel bilgiler verilecek akabinde Axel Olrik ve "Halk Anlatılarının Epik Kuralları” bağlamında Narspi Manzumesi metin merkezli bir yaklaşımla değerlendirmeye tabii tutulacaktır.

\section{Konstantin Vasil'yeviç İvanov ve Narspi Manzumesi}

Konstantin Vasil'yeviç İvanov, 1890 tarihinde günümüzde Başkurdistan Cumhuriyeti sınırları içerisinde kalan Pelebey ilçesinin Slakbaş köyünde dünyaya gelmiştir. Eğitimli bir ailenin çocuğu olan İvanov, 1903 yılında girdiği Simbir Öğretmen Okulu’ndan 1907 yılında siyasî öğrenci hareketlerine katıldığı gerekçesiyle atılmış; aynı yıl Y. Ya. Yakovlev'in isteği üzerine Simbir'de Çuvaşça eserlerin yayımlanması faaliyetlerine katılmıştır. Bu sırada tercüme çalışmalarına da başlayan İvanov; Nekrasov, Lermantov, Kotsov vb. klasik edebiyatçıların eserlerini ana diline kazandırmış; ayrıca yaptığı folklor derlemeleri neticesinde artan deneyim ve birikimlerinden de faydalanarak kendi eserlerini: Narspi, $\dot{I} k \square H \square r$, Tǔlĭh Arĭm ve Demir Tǔla'yı vücuda getirmiştir. 13 Mart 1915 tarihinde, henüz yirmi beş yaşındayken vefat etmiş; doğduğu köyde defnedilmiştir.

Konstantin İvanov'un Narspi'si Çuvaş edebiyatının bir klasiği olarak bugüne kadar değerini yitirmemiştir. Çuvaş Türkçesi ve diğer dünya dillerinde çok sayıda baskısı yapılan manzumenin ilk yayını, 1908 yılında Simbir'de “Çuvaş Masalları ve Anlatmaları Çuvaş Hikâyeleri” adlı kitapta yapılmıştır.

Yüzyıllarca varlığını sözlü gelenek üzerinden devam ettiren Çuvaş edebiyatı, 19 yy. başlarında yazılı hale gelmeye başlamıştır. Narspi, bu süreçte içerik olarak araştırmacılara daima kıymetli bilgiler sunmuş ve bu nedenle de sıkça çalışmalara kaynaklık etmiştir. Bu konuya ayrılmış müstakil çalışmaların yanı sıra, Çuvaş modern edebiyatının başlangıç dönemlerini içine alan ve Narspi manzumesine ilişkin birçok çalışmada sık sık folklor-edebiyat ilişkisi irdelenmiştir.

Eserde, zengin bir köylü kızı olan Narspi’nin fakir Setner’e olan aşkı, zengin babanın kızını yine zengin birisi olan Tıhtaman'la evlendirmesi ve ardından da bütün kahramanların ölümü ile neticelenen trajik

3 Bu kısımda yer alan bilgiler Bülent Bayram'ın “Konstantin İvanov’un Narspi Manzumesinde Geleneksel Çuvaş İnançları"Modern Türklük Araştırmaları Dergisi, C.8, S.2, Haziran 2011 ve Emine Yılmaz, "“Narspi” TDK Yayınları, Ankara, 2006 eserlerinden hülasa edilmiştir. Aksi belirtilmeyen durumlarda bilgiler bu eserlerden nakledilmiştir. 
olaylar dizisi işlenmektedir. Konu bakımından trajik sonla biten Türk halk hikâyelerine benzerliği ile dikkat çeken manzumenin yalnızca bu yönü bile müstakil bir çalışmanın konusu olacak kadar dikkat çekicidir. Manzume, epizotlar olarak kabul edebileceğimiz bölümlere ayrılmıştır. Her bir bölüm kendi içerisinde konu bakımından bir bütünlük göstermektedir. Manzume şu bölümlere ayrılmıştır:

1. Silpi Köyünde: Silpi adlı köy, tabiat, evler, insanlar ve onların hayatlarından kesitler canlı benzetmelerle tasvir edilir. Silpi köyü, oldukça güzel ve canlı bir şekilde betimlenmiştir. (1-16o.dizeler)

2. Sarı Kız: Manzumenin başkahramanı Narspi, babası Miheter ve genç kızın sevdiği genç Setner hakkındaki dizeler bu bölümle başlar. Narspi’nin güzelliğinin tasvir edildiği bu kısımda, onun Silpi köyünün en güzel kızı olduğuna vurgu yapılır. Narspi'nin ardından babası Miheter ve onun serveti üzerine söz söylenir. Miheter’in ardından Narspi'nin sevdiği Setner ve onun yoksul yaşamına ilişkin olarak manzume devam eder. Narspi'nin gerçekleşmesini istemediği düğün nedeniyle duyduğu üzüntü de ilk defa bu bölümde dile getirilir. (161-319.dizeler)

3. Simik Akşamı: Narspi ile Setner, pınar başında buluşurlar. Narspi, yakın zamanda Huşı̆lka köyünden zengin Tıhtaman'la düğününün gerçekleşeceğini söyler. Simik gelir ve düğün dernek kurulur. Kız ne kadar yalvarsa da düğüne engel olamaz. Yaşlı damat çıkar gelir. Çuvaş geleneklerine göre düğüne başlanır.(320-559.dizeler)

4. Düğün: Simik geleneğine göre, tüm Çuvaşlar banyo yapmalarının ardından, düğüne yeni ve temiz elbiseleri ile giderler. Düğün, Narspi'nin bütün isteksizliğine ve üzüntüsüne rağmen başlamıştır ve devam etmektedir.(560-663.dizeler)

5. Falcıda: Setner'in annesi oğluna ilişen kötülük nedeniyle falcıya gider. Falcıya derdini anlatır. Falcı, Setner'in derdinin kötü ruhlar tarafından verilen bir dert olmadığını, bunun bir kader olduğunu söyler. Yapılacak bir şey yoktur. Setner kaderini yaşamaya mecburdur.(664-775.dizeler)

6. Kaçış: Güneş batar, düğün dağılır. Narspi bu son gecesini Setner'le geçirmek ister. Setner'le Narspi buluşur. Gece Setner'le Narspi'nin kaçtığı anlaşılır. Üç atlı onları takip eder. Atlılar onları yakalar. Narspi’nin babası Setner’i döver. Olup bitenden henüz damadın haberi yoktur. Düğün, hiçbir şey olmamış gibi devam eder.(776-913.dizeler)

7. İki Düğün: Erkek alayı kızın köyüne gelir. Erkek düğün alayı Çuvaş geleneklerine göre karşılanır. Üç gün devam eden düğ̈̈nün ardından kızı alan erkek evi Huşı̆lka'ya doğru yola çıar. Setner ve Narspi bu şekilde ayrılırlar.(914-1053.dizeler)

8. Huşŭlka'da: Gelini getiren düğün alayı damadın köyünde geleneklere göre içkiyle karşılanır. Setner, gizlice kızla damadın konuşmalarını dinler. Tıhtaman artık dizginlerin kendinde olduğunu söyler. Tıhtaman, geleneklere göre misafirlerini ağırlar. Kızı getiren alay izzet ikramın ardından Silpi’ye doğru yola çıkar. (1054-1205.dizeler)

9. Simik Geçince: Düğün ve simik geçer, hayat normale döner. Narspi yeni çevresinde sadece kaynının çocuğu Sentti'yi sever, onunla konuşup kendini avutur. Bu arada Thtaman hergün Narspi'ye eziyet etmektedir. Tıhtaman'ın bir misafiri düğün esnasında Setner'le Narspi’nin kaçışını ona anlatır. Bunun üzerine Tihtaman, Narspi'ye daha da fazla eziyet eder. (1206-1321.dizeler) 
10. Narspi İşi: Yaz gelir ve Narspi kocasının eziyetini çekmektense onu öldürmeye karar verir. Narspi kocasına zehirli çorba hazırlar ve bu çorbayı içen Tıhtaman ölür. Kocasını öldüren Narspi, Huşı̆lka'dan kaçar. (1322-1561.dizeler)

11. Silpi'de: Silpi'de hayat normal seyrinde devam ederken Setner etraftaki dedikodulardan çok üzülmektedir. Bir gün tarlada çalışanlar evlerine dönerken Setner de tek başına ormana gider. (15621621.dizeler)

12. Ormanda: Setner ve Narspi ormanda buluşurlar. Onların buluşmasıyla her şey tersine döner, ormanın kara bulutu dağılır, güneş parlar. (1622-1737.dizeler)

13. Baba-Anne: Bütün bunlar olup biterken Setner’in anne ve babası evde oturmaktadır. Bu bölümde eve gelen Narspi'nin anne ve babasıyla karşlıklı konuşmaları yer alır. Anne babasına kendisini küçük yaşta sevmediği kişiye verdiklerini söylese de, anne ve babası kendi yaptıklarının doğru olduğunu iddia ederler. Anne ve babası her şeye rağmen onun Setner'le evlenmesine karşı çıkar. Narspi'nin anne ve babası, onların yanından beddua ederek ayrılırlar.(1738-1957.dizeler)

Dört Ölü: Silpi'de herkes uykudayken iki araba gelir. Arabayla gelen hırsızlar Miheter'in yedi hizmetçisini içkiyle uyutup Miheter'le karısını öldürüp onları soyarlar. Onların başına gelenleri duyup gelen Setner de hırsızlar tarafından öldürülür. Köylüler cenazeleri defnederler ve Narspi'nin cesedini de meşeye asılmış halde bulurlar.( 1958- 2097.dizeler)

Narspi’nin yazılışında halk edebiyatı ürünlerinden şekil, konu ve üslup bakımından faydalanıldığını; İvanov'un eserini yazdığı dönemde derlenmiş halde bulunan ya da sözlü gelenekte halen yaşayan halk edebiyatı örneklerini büyük bir ustalıkla eserine alıp, işlediğini gösteren örnekler çeşitli araştırmacılar tarafından tespit edilmiş; ${ }^{4}$ konu hakkında söylenilebilecek yeni söz imkânını ortadan kaldırmıştır.

İvanov'un kaleme aldığı eserde halk anlatıları yansımaları sadece motif, tema ve konudan ibaret değildir. Halk anlatılarının yapısal unsurları da İvanov'un eserinin belirleyici özelliklerindendir. Bu sebeple çalışmamızda yapısal olarak Narspi manzumesini ele almayı uygun gördük.

\section{Axel Olrik ve Halk Anlatılarının Epik Kuralları}

XIX. yüzyılda bağımsız bir disiplin olarak kurumlaşan halkbilimi, "bir topluluğun geleneksel ve anonim dünya görüşünü ve bunun dışa vurumları olarak kabul edilen, söze, harekete ve nesneye dayalı olarak ifade edilen her türlü anlamlı formu ve bunların oluşumları, geliştirilip ve pekiştirilmelerine yönelik iletişim olaylarının içinde konu edildiği bir bilim dalıdır" (Çobanoğlu, 2002, s.20). Bu bağlamda tarihi süreçte halkbiliminin araştırma sahasına giren anlatıların irdelendiği farklı kuram, teori ve araştırma yöntemleri ortaya çıkmıştır. "Halkbilimi araştırma, inceleme kuram ve yöntemleri genel olarak iki ana grupta toplanmaktadır. Bunlardan bir kısmı halk bilgisi metinlerini temel alarak oluşturulmuş ve diğer bir kısmı da metnin de içinde yer aldığı icrayı (performans) ve metnin yaratıldığı sosyal çevreyi esas almıştır." (Ekici, 2004, s.86). Bu noktada metin merkezli yaklaşımlardan olan Tarihi-Coğrafi Fin Kuramı, İskandinav ülkelerinin folklorik metinlerinin sistematize edildiği araştırma çizgisine sahip bir

\footnotetext{
$4 \quad$ Bkz: Bülent Bayram “Konstantin İvanov'un Narspi Manzumesinde Geleneksel Çuvaş İnançları'Modern Türklük Araştırmaları Dergisi, C.8, S.2, Haziran 2011 kaynakça kısmı: (Sidorova:1972, Zahemskiy: 1978-1982, vd). 
okuma biçimidir. Kuram, temeli itibariyle sözlü halk yaratmalarının ne zaman ve nerede yaratıldığını, onun muhtemel ilk şeklinin ne olduğunu belirlemeyi amaçlar (Çiftçi, 2013, s.520).5

Tarihî-Coğrafî Fin Kuramı'nın genişlemesini ve halk anlatılarının yapısal bakımdan çözümlemesini sağlayarak; Tarihi-Coğrafi Fin Okulu'na teorik bir katkı sunan Danimarkalı halkbilimci Axel Olrik, "Epik Yasalar Teorisi” adını verdiği çalışmasında herhangi birinin farklı halklara ait metinleri okurken yabancılık hissetmediğini belirtir ve bunun tesadüf olmayacağı üzerinde durur. Bunu açıklayan "ilkel insanın ortak zihin yapısı" ve "bu özelliğe uygun doğa kavramı ve ilkel mitoloji”nin yeterli olmadığını düşünür ve ayrıntılarda da benzeşmelerin olduğu tespitini ileri sürer. Bu tanışıklık hissini oluşturan benzerlikleri de, "halk anlatılarının epik kuralları olarak" kuramsal bir çerçeveye oturtur (Çiftçi, 2013, s.520). Bu bağlamda A. Olrik'in teorisi, bir halk anlatısı içinde belli temel yapıların bulunduğunu ortaya koyar.

"A. Olrik'e göre halk anlatılarının epik kuralları tamamen nevi şahsına münhasır bir olgu olan kültürün ayrılmaz bir parçasıdır ve buna göre bir halk âşı̆̆ı veya destancı bir kez anlatmaya başladı mı hiç farkında olmasa da ister istemez kontrolünde olduğu bu kanunları takip etmek durumundadır” (Çobanoğlu, 2002, s.115).

Axel Olrik halk anlatılarıyla ilgilenen herhangi bir kimsenin uzaktaki bir halkın edebiyatını okuyunca, bu halk ve onun geleneksel anlatılarının o kimseye şimdiye kadar tamamen yabancı olsa bile, bu anlatılarla daha önce karşılaşmış gibi bir duyguya kapıldığını vurgular (Olrik, 1994, s.2). Dolayısıyla kendi çevremizdeki bildiğimiz anlatılarla yabancı olduğumuz bir toplumun anlatıları arasında bir takım yapı ve işleyiş benzerlikleri hissedebiliriz.

Bu bağlamda asıl üzerinde düşünülmesi gereken nokta farklı toplumlara ait anlatılardaki birtakım ayrıntıların nasıl bir benzerlik gösterdiği ve bunların belli bir kural teşkil edip etmediğidir. Bu konu üzerinde çalışmalarını yürüten Olrik, yalnızca bir masal (märchen) biyolojisi veya sadece bir mit sınıflaması elde etmek için değil fakat sage adı verilen daha geniş bir kategori üzerinde daha sistemli bir bilim elde etmek için bu yaygın benzerliklerin bir araya getirilerek, bütün bu sage biçimlerinin meydana getirilmesinde ortak olan kurallara "Halk Anlatılarının Epik Kuralları" denebileceğini belirtir (Tuncel, 2015, s.210).

Olrik’in belirttiği epik kurallar şunlardır:

1.Giriş ve Bitiriş Kuralı

2. Yineleme Kuralı

3. Üçleme Kuralı

4. Bir Sahnede İki Kuralı

5.Zitllk Kuralı

6. İkizler Kuralı
7. İlk ve Son Durumun Önemi Kuralı

8. Anlatımda Tek Çizgililik Kuralı

9.Kalıplaştırma Kuralı

10. Anlatı Mantığ Kuralı

11. Büyük Tablo Sahnesi Kuralı Kuramla ilgili geniş bilgi için bkz: Özkul Çobanoğlu, Halk Bilimi Kuramları ve Araştırma Yöntemleri Tarihine
Giriş, Akçağ Yayınları, Ankara 2002. 
12.Tek Entrika Kuralı ve Epik Birlik- İdeal Epik Birlik Kuralı
13. Dikkati Baş Kahraman Üzerine Toplama Kuralı.

\section{Halk Anlatılarının Epik Kuralları Çerçevesinde Narspi Manzumesi}

Narspi manzumesinin fiktif yapısı incelendiğinde eserde, Olrik tarafından belirlenen epik yasaların/kuralların sırasıyla yer aldı̆̆ı görülmektedir. Ana vakanın sahneleniş tarzı ve anlatının sonlandırılması, eserde leitmotiv değerindeki-özellikle belirli durum tasvirlerinde tercih edilen kelimeler- bazı tekrarlar, 3, 7 gibi formülistik sayıların kullanılışı, eserdeki vakarlın birliği, sıralanışı ve kalıplaşma, büyük tablo sahnesi gibi özellikler eserdeki belli başlı epik kurallardandır.

\section{Giriş ve Bitiriş Kuralı}

Olrik, "Giriş ve Bitiriş Kuralı”nın en bilindik kural olduğunu belirtir. Halk anlatılarının belli bir başlayış ve bitiriş özelliği vardır. Anlatılar aniden başlamaz. Belli açılış, coşkunluk, durgunluk ve yöreye özgü bitirişle tamamlanır (Ekici, 2004, s.91). Anlatı çoğu zaman başlıca kişilerden birinin başına gelen bir felaketi içeren sonuç olayından sonra coşkunluktan durgunluğa giderek biter(Olrik, 1994, s.2-3).

Narspi manzumesine baktığımızda anlatının birden bire başlamadığını görürüz. Eserde başkahramanın tanıtıldığ bölümünden önce, vakalara geçilmeden evvel Narspi’nin doğup-büyüdüğü Silpi köyünün tasviri yapilır:
1.Mart ayı sonlarında
5. Kara tepeler, dağlar
9.Soğuk, kötü kış biter
2.Güneş bakar sıcacık
6. Karı eridiğinden
10.Gider üzüle üzüle
3.Çuvaş köyü Silpi'de
7.Yeșerir güçlü otlar
11.Soğuk gözyaşı döker,
4.Kar erir çabucacık
8.Güneş ısıttığından
12.Üzülür geçen güne.

Bu kısımda Silpi köyünde kıştan bahara geçişin betimlenişinde, gündelik Çuvaş köy hayatının, fiziksel ve sosyal çevrenin tasvirinde sahnelerin coşkunluğa doğru evrildiği görülür. Eser, giriş ve bitiriş kuralına uygun olarak, felaket içeren bir sonuçla, Miheter, karısı, Setner, gibi başlıca kahramanların ölümü ve nihayetinde Narspi'nin kendini asması ile neticelenir ve coşkunluktan durgunluğa giderek eser tamamlanır:

2054. Büyük mezarlıktalar

2055. Üç ölü var çukurda

2056. Güzel yiğit Setner'de

2057. Yatmış meşe tabutta

Eserin bitiş kısmı:
2058. Herkes güneye doğru

2059. Yürümeye başladı

2060. Narspi'yi ölü bulup

2061. Öylece kalakaldı
2062.Arayanlar döndüler

2063.Çatlatarak atları

2064. Kendirlikte meşeye

2065.Asmış kendini Narspi

${ }^{1}$ İnceleme, Emine Yılmaz’n ““‘Narspi” TDK Yayınları, Ankara, 2006 künyeli eser üzerinden yapılmıştır. 
2090. Tabuta yatıverdi

2091. Adı kaldı geride

2092. Hüzünlü şarkıları

2093. Insanların aklında
2094.Şimdi bile Silpi'de,

2095.Hatırlanır zavallı.

2096.Yağmur yağmazsa eğer,

2097.Sularlar toprağını.

\section{Yineleme ve Üçleme Kuralı}

Halk anlatıları ayrıntıya inmez, bunun yerine benzer durumlarda aynı tanımlama ve tasvirler yinelenir. Halk anlatılarında yineleme gerilim yaratmak için değil, boşlukları doldurmak için kullanılır (Ekici, 2004, s.91) "Yineleme kuralı", Olrik'e göre halk anlatılarının önemli bir parçasıdır. Yinelemenin aynı zamanda sayılarla da alakalı olduğu üzerinde duran Olrik, üç ve yedi gibi sayılarının toplam soyut nicelikleri belirttiğini söyler. Birçok kadim kültürde karşımıza çıkan üçler sayısının halk anlatılarında belirgin bir şekilde yer aldığı tespitini ekler (Olrik, 1994, s.2).

"Yineleme" ve "üçleme kuralı" açısından Narspi”ye bakacak olursak eserin özellikle fiziksel çevre ve doğa tasvirlerinin yapıldığını yerlerde aynı sıfat ve tasvirlerin yinelenerek, söz tekrarlarının yapıldı̆̆ görülmektedir: Kara kuş, kara orman, kara toprak, kara bulut, kara ev vb. Bununla birlikte bazı ifadelerin farklı yerlerde kurala uygun olarak boşlukları doldurmak adına yinelendiği görülür:

836. Üç tane at ormanda

837. İz sürerek koşuyor

838. Her tarafa bakınıp

839. Bir tane iz aryor

852. Üç tane at ormanda

853. İz sürerek koşuyor

854. Her tarafa bakınıp

855. Bir tane iz ariyor
1238.Yeni gelin Narspi kız

1239.Sürekli yaş döküyor

1240.Kaynının çocuğunu

1241.Tek Senti'yi seviyor

1242. Yeni gelin Narspi kız

1243. Sürekli yaş döküyor

1244. Senti ile konuşup

1245.Kendini av

utuyor

Eserde basit sıfatlara yer verilmekle birlikte eylemlerin en çok ulaç biçimi kullanılmıştır. Bu da esere sürekli bir hareket, canlılık ve süreklilik sağlar. Eylemlerin çok kullanılması, doğaya bağımlı, göçebe bir toplumun izlerini yansıtır. Eser bu özelliğiyle eski Türk halk şiirine yaklaşır (Yılmaz, 2006,s.23).

Bununla birlikte üçleme kuralına uygun olarak sıkça 3 sayısının kullanıldığı da görülmektedir:

836. Üç tane at ormanda

852. Üç tane at ormanda
871. Üç at yaklaşır

974.Üç gün düğün yaptılar 


\section{Bir Sahnede İki Kuralı}

Halk anlatılarında olayların yaşandığı sahnelerde sadece iki kişi yer alabilir. Bir sahnede üçüncü kişiye yer verilmez. Bu kural aynı zamanda bir sonraki kural olan zıtlık kuralını da tamamlamaktadır (Ekici, 2004, s.92) Narpi manzumesine baktığımızda bu kuralın işlediğini görürüz. Yazar eserini 14 başlık altında toplamıştır. Bütün bölümlerde genel olarak aynı anda iki kişinin varlı̆̆ını görülmekte, bölümlerde aynı anda iki kişinin- Narspi-Setner, Narspi-Setni, Miheter-Narspi Yaşlı kadın-Miheterkonuşmalarını görürüz.

\section{Zitlık Kuralı}

Olrik'e göre anlatıda her zaman kutuplaşma vardır. Bu temel zıtlık, epik yapının önemli bir kuralıdır: genç-ihtiyar, büyük ve küçük, iyi ve kötü. Bu kural halk anlatılarında birbirine zıt kişi ve olayların yer alması kuralıdır (Ekici, 2004, s.92). Eserde bu kurala en uygun örnek olarak; yoksulluğu ve merhameti ile öne çıan Narspi'nin sevgilisi genç Setner'e karşılık babasının zorla evlendirdiği zengin, acımasız ve yaşlı Tıhtaman verilebilir. Birbirine zıt kahraman örneğinin yanı sıra eserin genelinde aynı dörtlüklerde zıt anlamlı kelimelerin kullanılışı da dikkat çekmektedir:

732.Soğuk günler gelecek

733.Donacak sscak kanı

774.Yalan diye dediğim
775.Ah ne yazık doğru mu?

664.Bir küçücük kara ev,

665. Ak pak adam sekide.

\section{İlk ve Son Durumun Önemi Kuralı}

Halk anlatısında bir sahneye bir sürü karakter ve nesne arka arkaya çıkarsa bunlardan en önemli kişi öne gelir. Ancak, asıl vurgulama en son gelen kişi üzerinedir. Anlatının ağırlık noktası da sonuncu kişi üzerinde kurgulanır (Ekici, 2004, s.92).

Narspi'nin “Dört Ölü” başlıklı son kısmında çoğu karakter peş peşe ortaya çıkar. Bu sahnelerde sırasıyla Narspi'nin babası Miheter, annesi ve Setner’in hırsızlar tarafından öldürüldüğünü, yedi hizmetçinin ise şarapla uyutulduğunu öğreniriz. Burada öne çlkarılan başat karakter hırsızlar olsa da yazar, geçirdiği şok nedeniyle yere yığılan Narspi'den diğer kahramanların durumundan sonra bahseder. Yani asıl vurgulama sahneye en son gelen Narspi üzerindedir ve bu durumdan sonra trajik intihar gelecektir. Bir başka ifadeyle İvanov, anlatının ağırlık noktasını ilk ve son durumun önemi kuralına uygun olarak Narspi üzerinden kurgulamıştır diyebiliriz.

\section{Anlatımda Tek Çizgililik Kuralı}

Halk anlatıları son derece yalındır. Bir olay çizgisi, başka olaylarla karışmaz. Anlatı düz bir çizgi üzerinde ilerletilir ve geri dönüş yapılmaz (Ekici, 2004, s.92) Eğer daha önceki olaylar hakkında bilgi vermek gerekiyorsa; bu bir konuşmanın içinde verilir (Olrik, 1994, s.4).

Narspi'ye baktığımızda anlatının belli bir sistemi olduğunu görürüz. Olaylar, her bir bölümde bir sonraki kısmın hazırlayıcısı/tamamlayıcısı niteliğinde ve tek çizgi üzerinde ilerlemektedir: Öncelikle 
Çuvaş köyü Silpi ve Narspi hakkında genel bir tasvir/bilgi verilir akabinde ise olaylar şu çizgide gelişir: Narspi'nin Setner'le buluşması, düğün, Setner'in annesinin falcıya gitmesi, son geceyi Setner'le geçirmek için Narspi’nin kaçışı, düğüne geri dönüşü, mutsuz giden evliliği ve eşini zehirleyerek kaçışı, anne-babasıyla konuşmaları sitem ve beddualar, Narspi'nin anne-babasının ve Setner’in öldürülmesi, Narspi’nin kendini asması. Görüldüğü üzere kurala uygun olarak olaylar çerçevesinde anlatı ileriye doğru tek çizgi halinde devam eder.

\section{Kalıplaştırma Kuralı}

Aynı türden iki karakter veya durum olduğu kadar farklı değil, olduğu kadar benzerdir. Gereksiz ayrıntılar atılmış ve sadece gerekli olanlar bırakılmıştır (Ekici, 2004, s.92). Bu yönüyle Narpi'de dikkat çeken husus yazarın 14 başlıkla verdiği eserinin çoğu bölümünü kalıplaşmış diyebileceğimiz ifade tarzlarıyla, güneşin/günün doğması-batmasıyla başlatmasıdır.

\section{Silpi Köyünde}

1.Mart ayı sonlarında

2.Güneş bakar sıcacık

Kaçış

776.Güneş kaybolduğunda

777.Silpi köyü susuyor
Simik Akşamı

322.Gümüş gibi de parlar

323.Suyu güneş altında

\section{İki Düğün}

914.Kızgın güneşi yazın

915.Sönmeye yüz tutunca

\section{Düğün}

560.Gün doğunca Silpi'de

561.Gece siyrilıverdi

\section{Narspi İşi}

1322.Güneş doğar, yükselir

1323.Yüce dağlar üstüne

Bununla birlikte aynı duyguyu vermek istediği durumlarda da tekrar ettiği sözcük grubu ya da cümlelerden de kalıplaştırma bağlamında söz edebiliriz:
1372.Anne-baba hatası
1376.Anne-baba hatası
1380.Anne-baba hatası
1373.Geride acı kaldı
1377.Yaşamak neye yarar?
1381.Sevdiğim kaldı yalnız

\section{Anlatı Mantığı Kuralı}

Halk anlatısının kendine özgü bir mantığı vardır. Anlatı içinde söz konusu olan temaların konunun ana hatlarını etkilemesi söz konusu olup, bu etkileme temanın konu içindeki ağırlığı ile doğru orantılıdır (Ekici, 2004, s.92). Narspi'de anlatı mantığına uygun olarak olaylar sebep-sonuç ilişkisine göre şekillenmektedir. Bir yanda Narspi'nin sevdiği Setner, diğer tarafta zorla evlendirildiği Tihtaman, eşinin eziyetleri, anne-babasının kendilerini haklı görmesi ve bedduaları, akabinde hırsızlar tarafın Narspi'nin anne-babası ve sevdiği genç Setner'in öldürülmesi sonucu yaşamanın bir anlamının olmadığını düşünerek intihar etmesi gibi olay zincirlerinde kurgusal bir bağ olsa da felakete, -yani trajik sona- Narspi'nin zorla evlendirilmesinin değil, hırsızların neden olması sebep-sonuç ilişkisi bakımından kurgusal bir zayıflık olarak görülebilir.

\section{Büyük Tablo Sahnesi Kuralı}


Halk anlatılarında bazı sahnelerde bütün kahramanlar bir araya getirilir ve anlatı doruğa ulaştırılır. $\mathrm{Bu}$ tür sahneler gerçeğe değil, hayale dayanır. Büyük tablo sahnelerinin bir geçicilik duygusu değil bir çeşit zaman içinde süreklilik niteliği taşıdı̆̆ı fark ediliyor (Ekici, 2004, s.92).

Narspi'de anlatının doruğa ulaştığı yer eserin “Dört Ölü” başlıklı son kısmıdır. Daha önce Narspi’nin zehirleyerek öldürdüğü Tihtaman hariç bütün kahramanlar bir aradadır. Bu sahnelerde anlatı/heyecan doruğa ulaşır. Narspi'nin babası Miheter, annesi, hırsızlar tarafından öldürülür ve köy ahalisinin vaveylaları-konuşmaları burada verilir.

\section{Tek Entrika Kuralı ve Epik Birlik- İdeal Epik Birlik Kuralı}

Halk anlatısının içindeki entrikalar gerçek değil, oldukça sağlam bir şekilde kurgulanmıştır ve sonuçsuz hiçbir entrika olayların içinde yer almaz. Epik birlik halk anlatısı içinde yer alan ve baştan itibaren ortaya çıkma olasılığı bulunan bütün anlatı unsurlarının olaylar yaratmasıdır. Öte yandan bir de ideal epik birlik vardır. Birçok anlatı öğeleri, kişiler arasındaki ilişkileri en iyi şekilde aydınlatmak için bir araya gelirler (Olrik, 1994, s.5).

Eserin başından sonuna kadar Narspi'nin merkez durumda olduğu olaylar sergilenirken epik birlik yönüyle ortaya çıkma olasılığı bulunan anlatı unsurlarının olaylar yarattı̆̆ını görmek mümkündür. Eserdeki olaylar tek bir entrika etrafında döner. O da Narspi'nin istemediği halde zorla evlendirilmek istenmesidir. Bu entrika yaşanan diğer olayların sebebi konumundadır ve sağlam bir şekilde kurgulanmıştır. Sevgililerin kaçışları, yakalandıktan sonra düğünün devam etmesi, Narpi’nin çaresiz evlenmesinin ardından yaşlı kocasını zehirlemesi, Setner’i üzüntülü gören annesinin falcıya gidişi vb. olaylar bu entrikanın doğurduğu olay zincirleri olarak görülebilir. Eserin “Kaçış” bölümünde Narspi, bu son gecesini Setner'le geçirmek ister. Setner'le Narspi ormanda buluşur. Narspi'nin Setner'le uyurken rüyasında babasını bir köpek olarak ormanda dolaşıyor görmesi ve hemen akabinde üç atlının onları yakalamaları Narspi’nin başına gelecekleri gösterir bir tarzda yani anlatıdaki olay seyrini açıklar şekilde bir birlik oluşturur. Narspi’nin babasının zengin olması ve kızını da zengin birine layık görmesi sonucu Tihtamanla evlendirmesi olay örgüsünde kişiler arasındaki ilişkileri aydınlatır niteliktedir.

\section{Dikkati Baş Kahraman Üzerine Toplama Kuralı}

Halk anlatısında dikkat her zaman ana kahraman üzerinde yoğunlaştırılır. Olrik'e göre anlatıda tarihsel olaylar anlatılıyorsa dikkat kahramanın üzerinde toplanır. Sage'de iki kahraman belirdiği zaman halk anlatısının nasıl geliştiğini görmek çok ilgi çekicidir. Bir tanesi her zaman gerçek baş kahramandır. Sage onun hikâyesiyle başlar ve bütün dış görünüşüyle o, en önemli karakterdir (Ekici, 2004, s.92).

Narspi manzumesinde Narspi merkez durumundadır. Başkahraman esere ismini de veren Narspi'dir. Bu yönüyle dikkatin başkahraman olarak Narspi üzerinde toplandığını söyleyebiliriz. Eser onun yaşadığı köyün tasviriyle başlar ve Narspi'nin merkezde olduğu olaylar eserin sonuna kadar onun etrafinda gelişir.

\section{Sonuç ve Değerlendirme}

Konstantin İvanov'un Narspi manzumesini metin merkezli bir yaklaşımla incelendiğimiz bu çalışmada Olrik tarafından belirlenen epik yasaların/kuralların eserde sırasıyla yer aldığı görülmektedir. Giriş ve bitiriş kuralı, ana vakanın sahneleniş tarzı, yinelemeler, üçleme kuralı, eserdeki vakarlın birliği, sıralanışı ve kalıplaşma gibi özellikler eserdeki belli başlı epik kurallardır. Bu durum bize Olrik’in 
kuramsal bir çerçeveye oturttuğu çalışmasının uygulama sahası olarak geleneksel halk anlatılarıyla sınırlı olmayıp; kurgusal, yaratıcısı belirli farklı edebi türler içinde kullanılabildiğini göstermektedir ki bu durumu İvanov'un gerek beslendiği sözlü kaynaklar gerekse zikredildiği üzere öğrencilik yıllarında yaptığı derleme faaliyetlerinin etkisiyle olsa gerek eserde halk anlatılarının konu, motif ve yapı açlarından yansımaları olarak görmekteyiz. Bilindiği üzere türü ne olursa olsun sonradan yazıya geçirilen veya yazılı olarak üretilen edebi metinler bütün diğer iletişim biçimlerinde olduğu gibi 'anlatıcı ve dinleyicinin' varlığı olmadan gerçekleşemez. Zira “edebî bir anlatıda konu, olay, kişi, zaman, mekân gibi öğeler malzeme niteliğindedir ve bu malzemeyi bir kompozisyon biçimine sokan, onu estetik bir metne dönüştüren anlatıcıdır.”(Aslan, 2007, s.55). Anlatıcıların varlığıyla kendini canlı kılan bir geleneğin olmadığı ortamlarda, halk bilgisi ürünleri yeni türler içinde ifadelerini bulmaktadır. Narspi manzumesi de kendi bünyesinde Çuvaş halk kültürünün çeşitli unsurlarını barındırması yönüyle folkloredebiyat ilişkisine örneklik teşkil eden kıymetli bir eser olarak karşımıza çıkmaktadır.

\section{Kaynakça}

Argunşah, H. (2010). “Geleneksel Anlatıdan Modern Anlatıya Kurgusal Devamllıklar” Prof.Dr. Harun Güngör Armağanı, İstanbul: Kesit.

Aslan, C.(2007) "Sait Faik Abasıyanık’ın Öykülerinde Anlatım Teknikleri” Doktora Tezi, Ankara Üniversitesi, Sosyal Bilimler Enstitüsü, Türk Dili ve Edebiyatı Anabilim Dalı, Ankara.

Bayram, B, (2011)“Konstantin İvanov’un Narspi Manzumesinde Geleneksel Çuvaş İnançları” Modern Türklük Araştırmaları Dergisi, C.8, S.2.

Boyraz, Ş. (2008) "Sözlü Anlatıların Sürekliliği Üzerine Düşünceler", Folklor / Edebiyat, Sayı: 54, Ankara.

Çobanoğlu,Ö. (2002). Halk Bilimi Kuramları ve Araştırma Yöntemleri Tarihine Giriş, 2. bs., Ankara: Akçă̆.

Çonoğlu, S.(2014). “Ata Govşudov’un Ferman Romanında Milli Kimliğin Yeniden İnşası Sürecinde Milli Kültür Unsurları” Bilig, Güz 2014, Sayı 71.

Çiftçi, F. (2013) “Axel Olrik’in Epik Yasaları Işığında Oğuz Kağan Destanı’na Bir Bakış” Turkish Studies, Volume 8/4.

Ekici, M. (2004). “Araştırma Yöntemleri”, Türk Halk Edebiyatı El Kitabı, (M.Öcal Oğuz vd.) Ankara: Grafiker.

Gökalp, Z. (2007). Kitaplar, (Yay.haz.Sabri Koz) İstanbul: YKY.

Jusdanis, G. (1998). Gecikmiş Modernlik ve Estetik Kültür, Milli Edebiyatın İcad Edilişi, İstanbul: Metis.

Karadeniz, A. (2005) "Anlatma Zorunluluğu”, Ankara, Hece Dergisi, Türk Öykücülüğü Özel Sayısı, Yıl 4, S.46/47, II. Basım, Eylül.

Köseoğlu, N. (1997). Milli Kültür ve Kimlik. İstanbul: Ötüken.

Olrik, A. (1994) "Halk Anlatılarının Epik Kuralları", Milli Folklor, C.3, S.23-S.24, Ankara.

Sanl, Y. Türkeli, "Edebiyat; Toplumsal Hafızanın, Geleneğin Kaybında, İnşasında Ne kadar Etkilidir?" Çankırı Karatekin Üniversitesi, Sosyal Bilimler Enstitüsü Dergisi, 2(2).

Tuncel,U. (2013) “Axel Olric’in Halk Anlatılarmın Epik Yasaları Bağlamında “Ağahk” Adh Karagöz Oyunu Çözümlemesi” IÜ.Türk Dili ve Edebiyatı Dergisi, Cilt/Sayı: XLVIII, İstanbul.

Yllmaz, E. (2006). Narspi, Ankara: TDK. 